\title{
Investigating diversity of pathogenic microbes in commercial bait trade water
}

\author{
Andrew R Mahon ${ }^{\text {Corresp., }}{ }^{1}$ ， Dean J. Horton ${ }^{1}$ ， Deric R. Learman ${ }^{1}$ ， Lucas R. Nathan ${ }^{2}$ ， Christopher L. Jerde ${ }^{3}$ \\ 1 Department of Biology, Institute for Great Lakes Research, Central Michigan University, Mount Pleasant, MI, United States \\ 2 Department of Natural Resources and the Environment, University of Connecticut, Storrs, CT, United States \\ 3 Marine Science Institute, University of California, Santa Barbara, Santa Barbara, CA, United States \\ Corresponding Author: Andrew R Mahon \\ Email address: mahon2a@cmich.edu
}

The recreational bait trade is a potential pathway for pathogen introduction and spread when anglers dump bait shop sourced water into aquatic systems. Despite this possibility, and previous recognition of the importance of the bait trade in the spread of aquatic invasive species (AIS), to date there has been no region wide survey documenting pathogens in retail bait shops. In this study we analyzed 96 environmental DNA samples from retail bait shops around the Great Lakes region to identify pathogens, targeting the V4 hypervariable region of the 16S rRNA gene. Additionally, we used samples from one site in Lake Michigan as a comparison to pathogen diversity and abundance in natural aquatic systems. Our results identified nine different groups of pathogens in the bait shop samples, including those that pose risks to both humans and fish species. Compared to wild sourced samples, the bait shops had higher relative abundance and greater taxonomic diversity. These findings suggest that the bait trade represents a potentially important pathway that could introduce and spread pathogens throughout the Great Lakes region. Improving pathogen screening and angler outreach should be used in combination to aid in preventing the future spread of high risk pathogens. 
1 Investigating diversity of pathogenic microbes in commercial bait trade water

2 Andrew R. Mahon ${ }^{1 *}$, Dean J. Horton ${ }^{1}$, Deric R. Learman ${ }^{1}$, Lucas R. Nathan ${ }^{1,2}$, Christopher L.

3 Jerde $^{3}$

4

5

6

7

8

$9{ }^{1}$ Department of Biology, Institute for Great Lakes Research, Central Michigan University, Mount

10 Pleasant, MI 48859 USA

11

12 2Department of Natual Resources and the Environment, University of Connecticut, Storrs, CT

1306269 USA

14

$15{ }^{3}$ Marine Science Institute, University of California, Santa Barbara, Santa Barbara, CA, 93106,

16 USA

17

18

19

$20 *$ corresponding author: mahon $2 \mathrm{a} @$ cmich.edu 


\section{Abstract (200 words)}

22 The recreational bait trade is a potential pathway for pathogen introduction and spread when

23 anglers dump bait shop sourced water into aquatic systems. Despite this possibility, and previous

24 recognition of the importance of the bait trade in the spread of aquatic invasive species (AIS), to

25 date there has been no region wide survey documenting pathogens in retail bait shops. In this

26 study we analyzed 96 environmental DNA samples from retail bait shops around the Great Lakes

27 region to identify pathogens, targeting the V4 hypervariable region of the 16S rRNA gene.

28 Additionally, we used samples from one site in Lake Michigan as a comparison to pathogen

29 diversity and abundance in natural aquatic systems. Our results identified nine different groups

30 of pathogens in the bait shop samples, including those that pose risks to both humans and fish

31 species. Compared to wild sourced samples, the bait shops had higher relative abundance and

32 greater taxonomic diversity. These findings suggest that the bait trade represents a potentially

33 important pathway that could introduce and spread pathogens throughout the Great Lakes region.

34 Improving pathogen screening and angler outreach should be used in combination to aid in

35 preventing the future spread of high risk pathogens.

\section{Introduction}

39 With over 30 million anglers in the United States and Canada, and with many of them using live

40 bait in the form small fish (USDI 2011, DFO 2012), there is a significant risk of invasive species

41 introduction and spread through the commercial bait trade vector (Drake \& Mandrak, 2014).

42 This is particularly alarming when commercial bait retailers are contaminated with invasive fish, 43 such as Goldfish (Carassius auratus), Round Goby (Neogobius melanostomus), Eurasian Rudd 
44 (Scardinius erythrophthalmus), and Silver Carp (Hypophthalmichthys molitrix) (Nathan et al.,

45 2015). Invasion risk significantly increases when anglers dump unused bait and water into the

46 lakes and rivers at the end of a fishing day (Drake \& Mandrak, 2014). However, this angling

47 behavior has the potential to introduce more than just invasive fish species into new areas. Smith

48 et al. (2012) revealed the water in which ornamental fish are transported contains a unique biota

49 of fish and human pathogens beyond those found in the fish themselves. Additionally, the

50 diversity of pathogens within wild and cultured baitfish is well studied (Goodwin et al., 2004;

51 Lowry \& Smith, 2007). As such, it is reasonable to suspect that water which contains bait fish

52 could also serve as a reservoir for pathogenic bacterial species. This raises the question, what

53 pathogens are found in the bait bucket water?

55 Pathogens have the potential to be very damaging to human and wildlife health (Daszak,

56 Cunningham \& Hyatt, 2000) and economically costly (Jenkins, 2012). With respect to fisheries,

57 pathogens can be spread between commercial operations and wild populations, resulting in

58 costly damages. Such was the case with amplified sea lice densities from farmed Atlantic

59 Salmon leading to the decline of native Coho and Pink Salmon populations in British Columbia,

60 Canada (Krkošek et al., 2007; 2009; 2011). The damages become more acute when the

61 pathogens in question are generalists and spread throughout a valuable fishery, such as with viral

62 hemorrhagic septicemia virus (VHSV) spread throughout the Laurentian Great Lakes

63 (Rothlisberger et al., 2010; Escobar et al., 2017). While VHSV is a known pathogen already in

64 the Great Lakes region, the identity and impact of other pathogens are largely unknown. 
66 In the summers of 2012 and 2013, we visited over 500 bait shops across the U.S. Great Lakes

67 states of Minnesota, Wisconsin, Illinois, Indiana, Michigan, Ohio, Pennsylvania and New York

68 to collect water samples from commercial bait tanks for use in environmental DNA (eDNA)

69 screening of invasive species (Mahon, Nathan \& Jerde, 2014; Nathan et al., 2015). Our

70 hypothesis was that if invasive species are in a bait tank, then the water would contain DNA

71 from sloughed tissue, cells, and organelles in the water, which could be filtered, extracted, and 72 screened using molecular tools to detect the invasive species (Ficetola et al., 2008; Jerde et al.,

73 2011; Simmons et al., 2016). Additional to our initial hypotheses, these extracted eDNA

74 samples also contain DNA from all organisms in the water, including potential pathogens,

75 similar to those evaluated by Smith et al. (2014) who screened water samples for pathogens in

76 the water of imported, ornamental fish.

78 Here, we repurpose the eDNA samples previously collected from commercial bait shops in the 79 search for Great Lakes invasive fish species and analyze them using similar methods to those 80 employed by Smith et al. (2014) to document putative pathogens. Our goal was to identify

81 pathogenic species present in the samples, compare the diversity and abudance of bait shop

82 sourced pathogens to Great Lake sourced pathogens, and evaluate the potential threat of unique,

83 bait sourced pathogens being spread in the Laurentian Great Lakes in a manner similar to that 84 documented for invasive species.

86 Methods

87 Sample Collection and DNA Extraction 
88 Two-liter water samples were collected from the bait holding tanks in commercial bait shops

89 from each of the states in the Laurentian Great Lakes basin (Table 1; Figure 1; for additional

90 collection details see Nathan et al. 2014). Samples were filtered through $\sim 1.5 \mu \mathrm{m}$ glass fiber

91 filter paper within $24 \mathrm{~h}$ of their collection. DNA was extracted from filtered samples using a

92 MOBio PowerWater DNA Isolation Kit (MoBio Laboratories) following manufacturer

93 recommendations. All samples for this study were collected and analyzed using previously

94 described quality assurance protocols (Mahon et al., 2010; Jerde et al., 2011; Mahon et al., 2013;

95 Jerde et al., 2013; Nathan et al., 2015). Samples were chosen for analyses based on two factors:

96 a) available DNA remaining from previous studies (Mahon, Nathan \& Jerde, 2014; Nathan et al.,

97 2015) and b) proportional number of samples (out of 96 total) based on availability from each

98 Great Lakes state where samples were collected. Upon consideration of those factors, samples

99 were then randomly chosen for inclusion in this study. Total number of samples used in this

100 study are listed in Table 1 by collection location. Because our previous collection site numbers

101 (i.e., bait shops) were not equal from all Great Lakes states, proportionally, some states had more

102 samples included in this investigation than others (Table 1). We chose to restrict our location

103 information for individual bait shops (names, street addresses) where sample collections were

104 taken to the U.S. state to conceal the identity of individual vendors.

105 Along with investigating water samples from commercial bait vendors, we included

106 sequence data collected from a location in northern Lake Michigan to provide a point of

107 comparison between water samples collected in commercial bait shops and in natural Great

108 Lakes ecosystems (Hengy et al., 2017); Figure 1). Five samples from one collection site were

109 included in this study to serve as a comparison to our bait shop sequencing data. Although the

110 Lake Michigan samples likely do not represent the true pathogenic diversity in the entire Great 
111 Lakes region, we included the wild samples to provide a comparison to the potential differences

112 between wild and bait sourced pathogens.

\section{Genetic Sequencing}

114 Genomic DNA extracted from each of the 96 eDNA samples was sent to the Michigan State

115 University Research Technology Support Facility for microbial amplicon sequencing. Amplicon

116 sequencing libraries targeting the V4 hypervariable region of the $16 \mathrm{~S}$ rRNA gene (515f/806r)

117 were made following the protocol described by (Kozich et al., 2013). After PCR amplification,

118 resulting amplicon products were normalized using Invitrogen's SequalPrep DNA normalization

119 plates, pooled and purified. Pooled amplicons were validated and quantified using Qubit

120 dsDNA, Caliper LabChipGX DNA, and Kapa Biosystems Illumina Library Quantification qPCR

121 assays. The pool of samples was then loaded on an Illumina MiSeq flow cell (v2) and sequenced

122 in a $2 \times 250 \mathrm{bp}$ paired end format with a 500 cycle v2 reagent cartridge. Base calling was done by

123 Illumina Real Time Analysis (RTA) v1.18.54 and the sequencing output was demultiplexed and

124 converted to FastQ format using Bcl2fastq v1.8.4.

125 Data filtering, QAQC, and analyses

126 Sequences were screened for quality using MOTHUR version 1.35.1 (Schloss et al., 2009)

127 following the MiSeq SOP (https://www.mothur.org). Paired-end reads were assembled into

128 contigs and were retained if they were between 251 and $254 \mathrm{bp}$ in length, contained $\leq 8$

129 homopolymers, and lacked ambiguous bases. Sequences were then aligned against the Silva (v.

130 119) rRNA database (Quast et al., 2013) and chimeric DNA sequences were screened for and

131 removed with UCHIME (Edgar et al., 2011). Sequences were classified using the Ribosomal 
132 Database Project (RDP) (training set v9; Cole et al., 2014). Reads identified as chloroplast,

133 mitochondrial, or eukaryotic DNA, as well as those with unknown classifications, were removed

134 from the dataset. Operational Taxonomic Units (OTUs) were clustered using a threshold of 0.03

135 sequence dissimilarity. Additionally, any OTUs that were represented less than twice in the

136 dataset were removed as a conservative measure. Following data processing, we then screened

137 our results for a targeted group of potential pathogens similar to those noted by Smith et al.

138 (2012) (Table 2) using standard NCBI BLAST searches (Altschul et al., 1990). The search for

139 putative pathogens was limited to those that were used in the study, Smith et al. (2014). This is

140 not an exhaustive list of pathogens of concern in the Great Lakes, however, it allows for a

141 comparison of putative pathogens that are related to the unique ecosystem found in bait tank

142 water. The search did include some known fecal indicator bacteria, E. coli, Enterococcus,

143 Staphylococcus, and Bacteroides (see reviews, Sinigalliano et al., 2010; Mclellan et al. 2015).

144 The data described here did not contain any OTUs that had enough genetic resolution to be 145 classed as E. coli.

146 The same approach for processing and analyzing the dataset, from sample collection

147 through data filtering, was applied to samples collected from Lake Michigan (Hengy et al., 148 2017). Briefly, five samples were collected and filtered $(0.2 \mu \mathrm{m})$ from St. John's Bay (Lake

149 Michigan), Beaver Island, Michigan, USA. DNA was extracted and sequenced targeting the V4

150 region of the $16 \mathrm{~s}$ rRNA gene as described above for the commercial bait shop samples. This set

151 of samples was chosen for a comparision site as it used the same amplicon region and sequcing

152 plateform as used in this study and was also available immediately for our use in this study.

153 Comparing different amplicon regions and sequencing plateforms have been shown to be

154 difficlult and could provide misleading information and conclusions (e.g. Claesson et al., 2010). 
155 Additionally, we used a Chi-square test to evaluate independence between bait shop sourced and

156 Lake Michigan sourced pathogen sequence counts. All tests were performed in Mathematica

157 (Wolfram Research, 2017).

158

159 Results

160 Sequence data associated with this study are available on the MG-RAST database (Meyer et al., 161 2008) under accession numbers mgm4791794.3 - mgm4791986.3 and as referenced in Hengy et 162 al. (2017). From our resulting sequence data of the V4 hypervariable region of the 16S rRNA 163 gene (515f/806r), a total of $1,594,572$ sequence reads (of 8,082,960 total assembled sequences)

164 matched the nine targeted groups listed in Table 2. Of these, Flavobacterium was the most

165 diverse (400 OTUs) and most abundant (1,173,491 sequences) taxonomic group of putative 166 pathogens (Table 3). Additionally, Flavobacterium was present in all of the eDNA samples

167 processed and sequenced as a part of this effort. Least common in our resulting data was 168 Plesiomonas, with a total of 17 reads found in the water sample from a single commercial bait

169 shop in Michigan and the resulting BLAST search matches were to an unknown strain. Further, 170 our results found that both potential human and fish pathogens were present in water samples 171 collected in the commercial bait trade (Table 3). While we restricted our study to pathogens in

172 trade (see Smith et al. 2012), our data from bait shop samples did show the presence of three 173 putative fecal indicator bacteria: Bacteroides (13 OTUs with 9828 total reads), Staphylococcus

174 (1 OTUs with 56356 total reads), and Enterococcus (1 OTUs with 3706 total reads). Future 175 investigations on these and other comparable datasets should investigate these organisms further. 176 
177 Compared to bait samples, the five water samples collected from one location in northern Lake

178 Michigan had only 5 of 9 of our chosen target groups present when sequenced and analyzed in

179 same fashion (Table 4). Additionally, numbers of OTUs for Lake Michigan targeted groups were

180 significantly lower (ranging from 1-39 total OTUs; Table 4). The Chi-square test indicated the

181 distribution of pathogens was different between Lake Michigan and Bait shops ( $p$-value $<0.001$, 182 d.f. $=8)$.

\section{Discussion}

In this study, we documented the presence of human and fish pathogens in commercial

186 bait retailers in the Great Lakes region using genomic surveillance. Compared to a sample

187 sourced from Lake Michigan, bait samples had higher counts and higher diversity of multiple

188 groups of pathogens. Bait samples collected for this study even found the presence of human

189 fecal indicator bacteria (Bacteroides, Staphylococcus, and Enterococcus). Given the number of

190 recreational anglers that use live bait and potentially dispose of bait bucket water into aqutic

191 systems, the bait trade represents a potential vector for introducing and spreading pathogens

192 throughout the Great Lakes. Along with this, angler's use of bait presents the possibility of

193 contact with the bait tank water increasing risk of exposure to these potential pathogens. While

194 the virulence of these organisms remains unknown, this still represents a distinct possibility of

195 transfer, spread, and/or infection when they are present in the system.

196 While most any water sample, be it from the holding water of an ornamental fish (Smith

197 et al., 2012) or a commercial bait shop, local pond, drinking water source, or from a Great Lake,

198 is expected to have some pathogenic biota, clearly there is a difference in the distribution and

199 diversity of pathogens contained within samples. Our dataset found no evidence of Vibrio, 
200 Campylobater, Francisella, or Pleasiomonas bacterial strains in the limited number of samples

201 from Lake Michigan water we sampled and sequenced, yet they comprised $1.5 \%$ of the

202 sequenced pathogens in bait shop sourced water. While admittedly rare in our bait shop samples,

203 these pathogens may be thriving or at some ecological advantage in bait shops or they may be at

204 undetectable levels in the natural system. In contrast, OTUs similar to Aeromonas pathogens

205 were nearly four times more abundant (as a percentage) in bait shops than in Lake Michigan

206 sourced water. This again demonstrates an important point about these data, where a high

207 percentage, i.e., dominant, microbes in bait water are potential pathogens, and in our Lake

208 Michigan sampling, dominant microbes were likely non-pathogens. A study by Fujimoto et al.

209 (2016) on lake water did not find OTUs classified as Vibrio, Mycobacterium, Aeromonas, or

210 Pleasiomonas but did find one OTU that can be classeifed as Campylobater and Francisella.

211 However, these were very rare as the study defined a total of 158,900 OTUs (Fujimoto et al.

212 2016). Although, in this study, the wild sourced Lake Michigan collections (from five samples

213 sequenced and included here), came from a relatively limited spatial extent, which likely

214 represent a fraction of the true pathogenic diversity in the Great Lakes, the contrast between the

215 wild and bait shop samples suggests a substantial variation between the two sources. Future

216 investigations should include a wider sampling effort from throughout the basin to make a more

217 direct comparison between these two sources of water samples.

218

219 Conclusions

220 Detection and identification of pathogens is not new to science with over 19,000 articles

221 published on pathogen detection in the last 10 years (from 2008-2018; IS Web of Science, query

222 on 3/15/18). Researchers have previously reported on pathogen identification from areas outside 
223 of water and the environment, including the food industry, defense, and clinical applications

224 (Lazcka, Campo \& Muñoz, 2007). Analytical methods for these industries include traditional

225 screening procedures (culturing and colony counts) through molecular methods and biosensors

226 (Lazcka, Campo \& Muñoz, 2007). However, the role bait water plays in pathogen transmission

227 is unclear.

228 In the United States, there are approximately 33 million people that participate in

229 recreational fishing (16 years of age and older) that account for an industry of over $\$ 48$ billion

230 annually and approximately 828,000 jobs (Southwick, 2012). Within this, the access to and the

231 use of live bait from commercial shops presents a need to ensure the safety of participants.

232 Spread of these pathogens is an ongoing important problem in the bait industry. Despite the

233 concern over pathogens in the industry, actions towards prevention of pathogen spread by

234 commercial vendors do not always address the issue (Connelly et al., 2018).

235 In this study, we note a number of potentially harmful pathogens in samples fully

236 accessible to the public. However, there are a number of caveats to this. First, potential

237 pathogens, albeit present in the samples as noted, could be at low levels and may never become

238 virulent. Additionally, the pathogenicity of the documented OTUs was not specifically tested in

239 this study. Second, there is no guarantee of spread from source (e.g., commercial shop) to

240 additional sites, or that bait water bacteria could become harmful to humans as the pathogens

241 may become damaged during transport or die when released into the environment, a similar

242 observation to that of the importance of propagule pressure in the invasive species literature

243 (Lockwood, Cassey \& Blackburn, 2005). However, while there are no guarantees for spread

244 and/or infection, the likely repeated introduction of these potentially dangerous strains of

245 organisms to the environment and as documented in the invasive species literature, even low 
246

247

248

249

250

251

252

253

254

255

256

257

258

259

260

261

262

263

264

265

266

267

268

269

270

271

272

273

274

275

276

277

278

279

280

281

282

283

probability survival and arrival can ultimately lead to establishment and damages of invasive species (Jerde \& Lewis, 2007; Jerde \& Bampfylde, 2009). Future screening and monitoring is needed to ensure safety for millions of participants in recreational fishing annually and also to the ecosystems where these harmful pathogens could be spread.

\section{Literature Cited}

Altschul SF, Gish W, Miller W, Myers EW, Lipman DJ 1990. Basic local alignment search tool. Journal of Molecular Biology 215:403-410. DOI: 10.1016/S0022-2836(05)80360-2.

Claesson MJ, Wang Q, O’Sullivan O, Greene-Diniz R, Cole JR, Ross RP, O’Toole PW 2010. Comparison of two next-generation sequencing technologies for resolving highly complex microbiota composition using tandem variable 16S rRNA gene regions. Nucleic Acids Research, 38(22), e200.

Cole JR, Wang Q, Fish JA, Chai B, McGarrell DM, Sun Y, Brown CT, Porras-Alfaro A, Kuske CR, Tiedje JM 2014. Ribosomal Database Project: data and tools for high throughput rRNA analysis. Nucleic Acids Research 42:D633-D642. DOI: 10.1093/nar/gkt1244.

Connelly NA, Lauber TB, Stedman RC, Knuth BA 2018. Bait dealers' roles in preventing the spread of aquatic invasive species and fish pathogens in the Great Lakes region. Journal of Great Lakes Research:1-7. DOI: 10.1016/j.jglr.2018.04.005.

Daszak P, Cunningham AA, Hyatt AD 2000. Emerging Infectious Diseases of Wildlife-- Threats to Biodiversity and Human Health. Science 287:443-449. DOI:

10.1126/science.287.5452.443.

DFO (Department of Fisheries and Oceans Canada). 2012. Survey of recreational fishing in Canada, 2010. Fisheries and Oceans Canada, Ottawa, Ontario.

Drake DAR, Mandrak NE 2014. Ecological Risk of Live Bait Fisheries: A New Angle on Selective Fishing. Fisheries 39:201-211.

Edgar RC, Haas BJ, Clemente JC, Quince C, Knight R 2011. UCHIME improves sensitivity and speed of chimera detection. Bioinformatics 27:2194-2200. DOI: 10.1093/bioinformatics/btr381.

Escobar LE, Kurath G, Escobar-Dodero J, Craft ME, Phelps NBD 2017. Potential distribution of the viral haemorrhagic septicaemia virus in the Great Lakes region. Journal of fish diseases 40:11-28. DOI: $10.1111 /$ jfd.12490.

Ficetola GF, Miaud C, Pompanon F, Taberlet P 2008. Species detection using environmental DNA from water samples. Biology Letters 4:423-425. DOI: 10.1098/rsbl.2008.0118.

Fujimoto M, Cavaletto J, Leibig JR, McCarthy A, Vanderploeg HA, Denef VJ 2016. Spatiotemporal distribution of bacterioplankton functional groups along a freshwater estuary to pelagic gradient in Lake Michigan. J. Great Lakes Res. 1036-1048.

Goodwin AE, Peterson JE, Meyers TR, Money DJ 2004. Transmission of Exotic Fish Viruses. Fisheries 29:19-23. DOI: 10.1577/1548-8446(2004)29[19:TOEFV]2.0.CO;2. 
284

285

286

287

288

289

290

291

292

293

294

295

296

297

298

299

300

301

302

303

304

305

306

307

308

309

310

311

312

313

314

315

316

317

318

319

320

321

322

323

324

325

326

327

328

329

Hengy MH, Horton DJ, Uzarski DG, Learman DR 2017. Microbial community diversity patterns are related to physical and chemical differences among temperate lakes near Beaver Island, MI. PeerJ 5:e3937. DOI: 10.7717/peerj.3937.

Jenkins PT 2012. Invasive animals and wildlife pathogens in the United States: the economic case for more risk assessments and regulation. Biological Invasions 15:243-248. DOI: 10.1007/s10530-012-0296-8.

Jerde CL, Bampfylde C 2009. Chance establishment for sexual, semelparous species: overcoming the Allee effect. The American Naturalist.

Jerde CL, Lewis MA 2007. Waiting for invasions: a framework for the arrival of nonindigenous species. The American Naturalist 170:1-9. DOI: 10.1086/518179.

Jerde CL, Chadderton WL, Mahon AR, Renshaw MA, Corush J, Budny ML, Mysorekar S, Lodge DM 2013. Detection of Asian carp DNA as part of a Great Lakes basin-wide surveillance program. Canadian Journal of Fisheries and Aquatic Sciences 70:522-526. DOI: $10.1139 /$ cjfas-2012-0478.

Jerde CL, Mahon AR, Chadderton WL, Lodge DM 2011. "Sight-unseen" detection of rare aquatic species using environmental DNA. Conservation Letters 4:150-157. DOI: 10.1111/j.1755-263X.2010.00158.x.

Kozich JJ, Westcott SL, Baxter NT, Highlander SK, Schloss PD 2013. Development of a dualindex sequencing strategy and curation pipeline for analyzing amplicon sequence data on the MiSeq Illumina sequencing platform. Applied and Environmental Microbiology 79:51125120. DOI: 10.1128/AEM.01043-13.

Krkošek M, Connors BM, Morton A, Lewis MA, Dill LM, Hilborn R 2011. Effects of parasites from salmon farms on productivity of wild salmon. Proceedings of the National Academy of Sciences 108:14700-14704. DOI: 10.1073/pnas.1101845108.

Krkošek M, Ford JS, Morton A, Lele S, Myers RA, Lewis MA 2007. Declining Wild Salmon Populations in Relation to Parasites from Farm Salmon. Science 318:1772-1775. DOI: 10.1126/science. 1148744.

Krkošek M, Morton A, Volpe JP, Lewis MA 2009. Sea lice and salmon population dynamics: effects of exposure time for migratory fish. Proceedings of the Royal Society B: Biological Sciences 276:2819-2828. DOI: 10.1098/rspb.2009.0317.

Lazcka O, Campo FJD, Muñoz FX 2007. Pathogen detection: A perspective of traditional methods and biosensors. Biosensors \& bioelectronics 22:1205-1217. DOI: 10.1016/j.bios.2006.06.036.

Lockwood JL, Cassey P, Blackburn T 2005. The role of propagule pressure in explaining species invasions. Trends in Ecology \& Evolution 20:223-228. DOI: 10.1016/j.tree.2005.02.004.

Lowry T, Smith SA 2007. Aquatic zoonoses associated with food, bait, ornamental, and tropical fish. Journal of the American Veterinary Medical Association 231:876-880. DOI: 10.2460/javma.231.6.876.

Mahon AR, Jerde CL, Galaska M, Bergner JL, Chadderton WL, Lodge DM, Hunter ME, Nico LG 2013. Validation of eDNA surveillance sensitivity for detection of Asian carps in controlled and field experiments. PloS one 8:e58316. DOI: 10.1371/journal.pone.0058316.t002.

Mahon AR, Nathan LR, Jerde CL 2014. Meta-genomic surveillance of invasive species in the bait trade. Conservation Genetics Resources 6:563-567. DOI: 10.1007/s12686-014-0213-9.

Mahon AR, Rohly A, Budny ML, Jerde CL, Chadderton WL, Lodge DM 2010. Environmental DNA Monitoring and Surveillance: Standard Operating Procedures. Report to the United 
States Army Corps of Engineers, Environmental Laboratories, Cooperative Environmental Studies Unit, Vicksburg, Mississippi. CESU agreement \#W912HZ08-02-0014, modification P00007.

McLellan SL, Fisher JC, Newton RJ 2015. The microbiome of urban waters. Int Microbiol. 18(3): 141-149.

Meyer F, Paarmann D, D'Souza M, Olson R, Glass EM, Kubal M, Paczian T, Rodriguez A, Stevens R, Wilke A, Wilkening J, Edwards RA 2008. The metagenomics RAST server - a public resource for the automatic phylogenetic and functional analysis of metagenomes. BMC Bioinformatics 9:386. DOI: 10.1186/1471-2105-9-386.

Nathan LR, Jerde CL, Budny ML, Mahon AR 2015. The Use of Environmental DNA in Invasive Species Surveillance of the Great Lakes Commercial Bait Trade. Conservation Biology:n/an/a. DOI: 10.1111/cobi.12381.

Quast C, Pruesse E, Yilmaz P, Gerken J, Schweer T, Yarza P, Peplies J, Glöckner FO 2013. The SILVA ribosomal RNA gene database project: improved data processing and web-based tools. Nucleic Acids Research 41:D590-D596. DOI: 10.1093/nar/gks1219.

Rothlisberger JD, Lodge DM, Cooke RM, Finnoff DC 2010. Future declines of the binational Laurentian Great Lakes fisheries: the importance of environmental and cultural change. Frontiers in Ecology and the Environment 8:239-244. DOI: 10.1890/090002.

Schloss PD, Westcott SL, Ryabin T, Hall JR, Hartmann M, Hollister EB, Lesniewski RA, Oakley BB, Parks DH, Robinson CJ, Sahl JW, Stres B, Thallinger GG, Van Horn DJ, Weber CF 2009. Introducing mothur: Open-Source, Platform-Independent, Community-Supported Software for Describing and Comparing Microbial Communities. Applied and Environmental Microbiology 75:7537-7541. DOI: 10.1128/AEM.01541-09.

Simmons M, Tucker A, Chadderton WL, Jerde CL, Mahon AR 2016. Active and passive environmental DNA surveillance of aquatic invasive species. Canadian Journal of Fisheries and Aquatic Sciences 73:76-83. DOI: 10.1139/cjfas-2015-0262.

Smith KF, Schmidt V, Rosen GE, Amaral-Zettler L 2012. Microbial Diversity and Potential Pathogens in Ornamental Fish Aquarium Water. PloS one 7:e39971. DOI: 10.1371/journal.pone.0039971.s004.

Sinigalliano CD, Fleisher JM, Gidley ML, Solo-Gabriele HM, Shibata T, Plano LRW, Elmir SM, Wanless D, Bartkowiak J, Roiteau R, Withum K, Abdelzaher AM, He G, Ortega C, Zhu X, Wright ME, Kish J, Hollenbeck J, Scott T, Backer LC, Fleming LE 2010. Traditional and molecular analyses for fecal indicator bacteria in non-point source subtropical recreational marine waters. Water research. 44: 3763-3772.

Southwick A 2012. Sportfishing in America: an economic force for conservation. Produced for the American Sportfishing Association (ASA) under a U.S. Fish and Wildlife Service (USFWS) Sport Fishing Restoration Grant (F12AP00137, VA M-26-R) awarded by the Association of Fish and Wildlife Agencies (AFWA):1-12.

U.S. Department of the Interior, U.S. Fish and Wildlife Service, and U.S. Department of Commerce, U.S. Census Bureau. 2011. National survey of fishing, hunting and wildlifeassociated recreation.

Wolfram Research, Inc. 2017. Mathematica, Version 11.2, Champaign, IL. 
375 Figure 1. Collection locations of bait water samples collected from commercial vendors utilized

376 in this study. Included are shop locations (black circles) and the sampling location for the Lake

377 Michigan water sample (black star) included in the dataset.

378

379

380 Table 1: Collection location (by U.S. state) and number of bait shop DNA samples used in the 381 study.

382

383 Table 2. List of bacterial pathogen groups that were searched for in our resulting data. Note that

384 while not all members of each group listed are known to cause the effects listed, these are "worst 385 case" scenarios for that genus/group.

386

387 Table 3. Reads and OTUs of targeted pathogen groups for bait sourced samples and their 388 virulence/pathogenic effects regardless of their origin. Note that Top/Notable matches from

389 BLAST results were for all top matches $>98 \%$ similar for the OTUs found.

390

391 Table 4. Reads and OTUs of targeted pathogen groups for the five Lake Michigan samples (one 392 collection location; Hengy et al. 2017) and their virulence/pathogenic effects regardless of their 393 origin. Note that Top/Notable matches from BLAST results were for all top matches $>98 \%$ 394 similar for the OTUs found. 395 396 
Figure 1

Map of collection locations for samples used in this study

Collection locations of bait water samples collected from commercial vendors utilized in this study. Included are shop locations (black circles) and the sampling location for the Lake Michigan water sample (black star) included in the dataset.

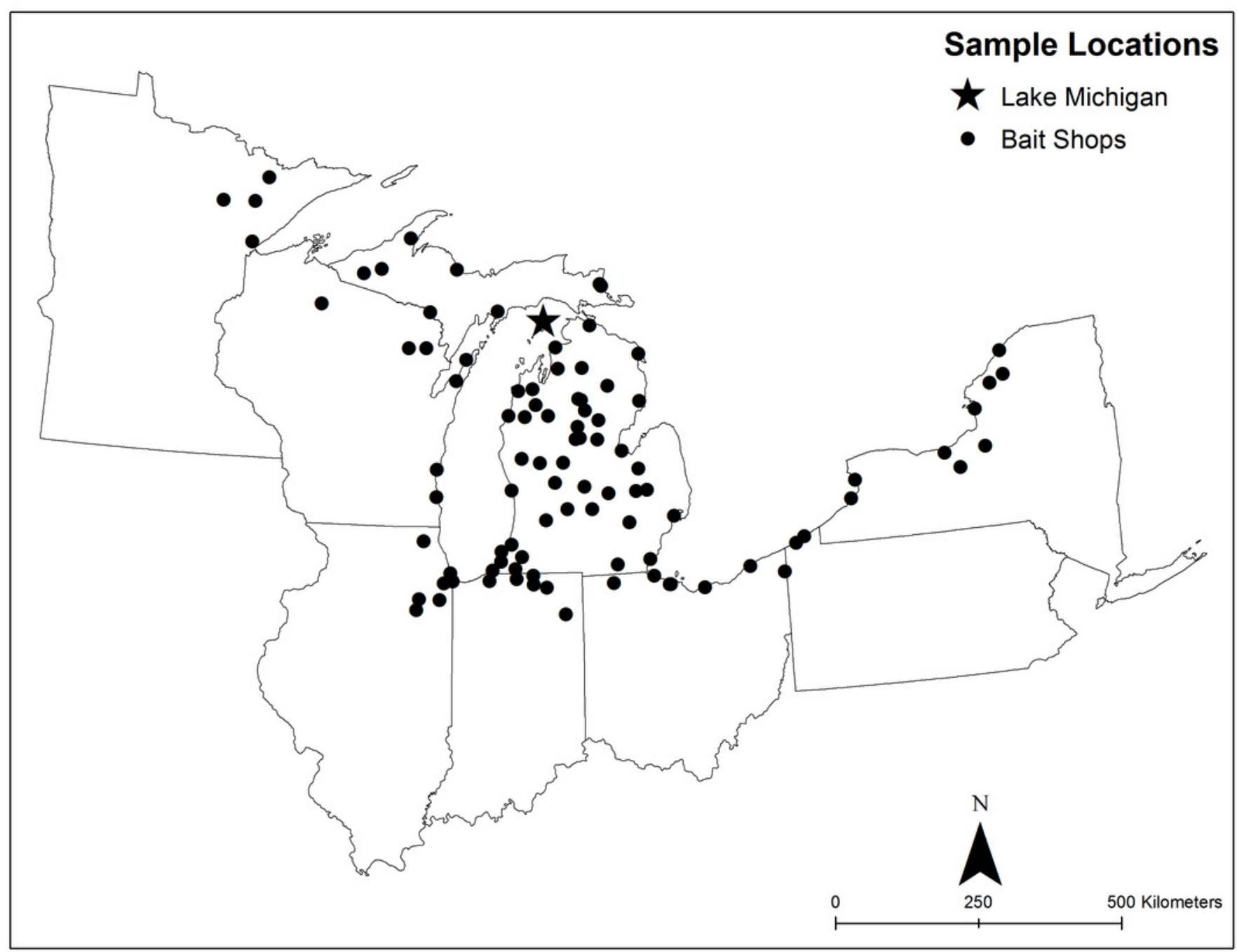




\section{Table $\mathbf{1}$ (on next page)}

Sample collection locations

Collection location (by U.S. state) and number of bait shop DNA samples used in the study. 


\begin{tabular}{|c|c|}
\hline State & Number of Samples \\
\hline IL & 6 \\
\hline IN & 7 \\
\hline MI & 53 \\
\hline MN & 4 \\
\hline NY & 9 \\
\hline OH & 7 \\
\hline PA & 2 \\
\hline WI & 8 \\
\hline
\end{tabular}

1 


\section{Table 2 (on next page)}

Pathogens screened

List of bacterial pathogen groups that were searched for in our resulting data. Note that while not all members of each group listed are known to cause the effects listed, these are "worst case" scenarios for that genus/group. 


\begin{tabular}{|c|l|}
\hline Pathogen & Some harmful effects caused by members of group \\
\hline Vibrio & $\begin{array}{l}\text { Some species can cause gastroenteritis, septicemia, } \\
\text { cholera }\end{array}$ \\
\hline Legionella & Legionnaires disease, Pontiac fever \\
\hline Mycobacterium & Tuberculosis, leprosy \\
\hline Coxiella & Q fever \\
\hline Campylobacter & campylobacteriosis (gastrointestinal infection) \\
\hline Francisella & $\begin{array}{l}\text { tularemia (rabbit fever), septicemia and invasive } \\
\text { systemic infections }\end{array}$ \\
\hline Plesiomonas & gasteroenteritis \\
\hline Flavobacterium & $\begin{array}{l}\text { Bacterial cold water disease on salmonids, rainbow } \\
\text { trout fry disease on rainbow trouts, cotton-wool } \\
\text { disease on freshwater fishes, the bacterial gill disease } \\
\text { on trouts. }\end{array}$ \\
\hline Salmonella & typhoid fever, paratyphoid fever, and food poisoning \\
\hline Giardia & Giardiasis \\
\hline Shigella & Shigellosis, dissentary \\
\hline Aeromonas & $\begin{array}{l}\text { Gastroenteritis and wound infections, with or without } \\
\text { bacteremia. }\end{array}$ \\
\hline
\end{tabular}

1 


\section{Table 3(on next page)}

Sequence reads bait shops

Reads and OTUs of targeted pathogen groups for bait sourced samples and their virulence/pathogenic effects regardless of their origin. Note that Top/Notable matches from BLAST results were for all top matches $>98 \%$ similar for the OTUs found. 


\begin{tabular}{|c|c|c|c|c|c|}
\hline & $\begin{array}{l}\text { Total number } \\
\text { reads in all } \\
\text { samples }\end{array}$ & $\begin{array}{l}\text { Highest \# reads in } \\
\text { single sample } \\
\text { (location) }\end{array}$ & $\begin{array}{l}\text { Total OTUs } \\
\text { found in } \\
\text { dataset from } \\
\text { all shops }\end{array}$ & $\begin{array}{l}\text { Present in \# of } \\
\text { samples (and \% } \\
\text { of samples) }\end{array}$ & Top/Notable matches (disease) \\
\hline Vibrio & 20977 & 6406 (MI) & 1 & $65(67.71 \%)$ & $\begin{array}{c}V . \text { cholerae (cholera), } V \text {. anguillarum (cultured } \\
\text { salmon pathogen) }\end{array}$ \\
\hline Legionella & 26419 & 7264 (WI) & 141 & $86(89.58 \%)$ & $\begin{array}{l}\text { L. maceachernii (pneumonia), L. pneumophilia } \\
\text { (Legionnaires disease), L. micdadei (Pontiac fever), } L \text {. } \\
\text { longbeachae (Pontiac fever) }\end{array}$ \\
\hline Mycobacterium & 164190 & $51052(\mathrm{WI})$ & 37 & $93(96.88 \%)$ & $\begin{array}{l}\text { M. tuberculosis (tuberculosis), M. bovis (TB in cattle), } \\
\text { M. lepromatosis (leprosy), M. microti (other mammal } \\
\text { TB), M. tusciae (chronic fibrosis from tap water), } M \text {. } \\
\text { mucogenicum (BSL 2, skin infections) }\end{array}$ \\
\hline Coxiella & 95 & $37(\mathrm{IN})$ & 6 & $7(7.29 \%)$ & Q fever (closest at 95\% match) \\
\hline Campylobacter & 1414 & $503(\mathrm{WI})$ & 2 & $5(5.21 \%)$ & $\begin{array}{l}\text { C. consisus (intestional disease), C. gracilis } \\
\text { (intestional disease) }\end{array}$ \\
\hline Francisella & 1164 & 485 (MI) & 1 & $17(17.71 \%)$ & F. philomiragia (rare human infection) \\
\hline Plesiomonas & 17 & $17(\mathrm{MI})$ & 1 & $1(1.04 \%)$ & Unknown strain. \\
\hline Flavobacterium & 1173491 & $64265(\mathrm{MN})$ & 400 & $100(100 \%)$ & $\begin{array}{l}\text { F. psychrophilum (bacterial cold water disease in } \\
\text { salmonids, rainbow trout fry disease), F. columnare } \\
\text { (cotton-wool disease in freshwater fish), } F \text {. } \\
\text { branchiophilum (bacterial gill disease in trout) }\end{array}$ \\
\hline Salmonella & - & - & - & - & Not present \\
\hline Giardia & - & - & - & - & Not present \\
\hline Shigella & - & - & - & - & Not present \\
\hline Aeromonas & 206805 & 10426 (MI) & 24 & 95 (98.95\%) & $\begin{array}{c}\text { A. veronii (human pathogen), A. salmonicida (virulent } \\
\text { salmon pathogen), A. schubertii (infection of Chana } \\
\text { argus!) }\end{array}$ \\
\hline
\end{tabular}

1 


\section{Table 4(on next page)}

Sequence data Lake MI

Reads and OTUs of targeted pathogen groups for the five Lake Michigan samples (one collection location; Hengy et al. 2017) and their virulence/pathogenic effects regardless of their origin. Note that Top/Notable matches from BLAST results were for all top matches $>98 \%$ similar for the OTUs found. 


\begin{tabular}{|c|c|c|c|c|c|}
\hline & $\begin{array}{l}\text { Total \# of } \\
\text { reads in all } \\
\text { samples }\end{array}$ & $\begin{array}{c}\text { Highest \# reads in } \\
\text { single } \\
\text { sample/location }\end{array}$ & $\begin{array}{l}\text { Total OTUs found in } \\
\text { dataset from all } \\
\text { samples }\end{array}$ & $\begin{array}{l}\text { Present in \# of } \\
\text { samples (and \% of } \\
\text { samples) }\end{array}$ & Top/Notable matches (disease) \\
\hline Vibrio & 0 & 0 & 0 & 0 & Not present \\
\hline Legionella & 16 & 4 & 11 & $5(100 \%)$ & $\begin{array}{c}\text { L. longbeachae, L. wadsworthii, } L \text {. } \\
\text { santicrucis }\end{array}$ \\
\hline Mycobacterium & 9 & 4 & 6 & $3(60 \%)$ & $\mathrm{n} / \mathrm{a}$ \\
\hline Coxiella & 1 & 1 & 1 & $1(20 \%)$ & \\
\hline Campylobacter & 0 & 0 & 0 & 0 & Not present \\
\hline Francisella & 0 & 0 & 0 & 0 & Not present \\
\hline Plesiomonas & 0 & 0 & 0 & 0 & Not present \\
\hline Flavobacterium & 1379 & 915 & 39 & $5(100 \%)$ & $\begin{array}{c}\text { Pseudomonas veronii, Pseudomonas } \\
\text { gessardi, Pseudomonas sp., Pseudomonas } \\
\text { fluorescens } \\
\end{array}$ \\
\hline Salmonella & - & - & - & - & Not present \\
\hline Giardia & - & - & - & - & Not present \\
\hline Shigella & - & - & - & - & Not present \\
\hline Aeromonas & 46 & 33 & 1 & $5(100 \%)$ & $\begin{array}{l}\text { Aeromonas jandaei, Aeromonas } \\
\text { allosaccharophilia, Aeromonas bivalvium, } \\
\text { Aeromonas molluscorum, Aeromonas } \\
\text { caviae, Aeromonas salmonicida, others (all } \\
100 \%) \text { A.c. causes necroticizing fasciatus }\end{array}$ \\
\hline
\end{tabular}

1 